\title{
Nomenclatural and taxonomic notes on some species of Gyrinidae (Coleoptera)
}

\author{
Hans FERY ${ }^{1)} \&$ Jiř́i HÁJEK ${ }^{2)}$ \\ 1) Räuschstraße 73, D-13509 Berlin, Germany; e-mail: hanfry@aol.com \\ ${ }^{2)}$ Department of Entomology, National Museum, Cirkusová 1740, CZ-193 00 Praha 9 - Horní Počernice, Czech Republic; e-mail: jiri.hajek@nm.cz
}

Accepted:
$2^{\text {nd }}$ February 2021
Published online:
$24^{\text {th }}$ February 2021

Zoobank: http://zoobank.org/urn:lsid:zoobank.org:pub:683E0FC9-6878-4915-9C27-E2C4A642ACF4

(C) 2021 The Authors. This work is licensed under the Creative Commons Attribution-NonCommercial-NoDerivs 3.0 Licence.

\begin{abstract}
Nomenclatural notes on the names of several species in the family Gyrinidae are provided. Six specific names are found to be junior homonyms. Three of them are replaced by nomina nova: Aulonogyrus marginatus (Aubé, 1838) by Aulonogyrus charlesaubei nom. nov., Gyrinus dubius Wallis, 1926 by Gyrinus suspectus nom. nov., and Macrogyrus (Andogyrus) colombicus australis (Brinck, 1977) by Macrogyrus (Andogyrus) colombicus brincki nom. nov. The other three junior homonyms were never considered congeneric with senior homonyms after the year 1899, and thus cannot not be replaced by new names: Gyretes dorsalis (Brullé, 1837), Macrogyrus australis (Brullé, 1835), and Andogyrus glaucus (Aubé, 1838); it is proposed that these names will be conserved by a ruling of the International Commission on Zoological Nomenclature. It is found that Enhydrus sulcatus (Forsberg, 1821) is a primary homonym and a junior subjective synonym of Enhydrus sulcatus (Wiedemann, 1821) in WIEDEMANN \& GERMAR (1821). The neotype is designated for Gyrinus striatus Fabricius, 1792, which is a senior primary homonym and a senior subjective synonym of $G$. striatus Olivier, 1792 (both currently in Aulonogyrus Motschulsky, 1853). Gyrinus striatus was published by Olivier not only in 1792, but again in the year 1795 (so far treated as the correct publishing year). To stabilise the nomenclature, one and the same specimen is designated simultaneously as the neotype for Gyrinus striatus Olivier, 1792, and G. striatus Olivier, 1795, and thus both names become objective synonyms. Gyrinus ovatus Klug, 1829 is a senior subjective synonym of Gyrinus gibbus Aubé, 1838 syn. nov. and of Gyrinus apicalis Sharp, 1878 syn. nov. Gyrinus racenisi Ochs, 1953 must be used as the valid name for Gyrinus ovatus sensu Aubé (1838b) (nec KLUG 1829). Lectotypes are designated for Gyrinus apicalis Sharp, 1878, Gyrinus gibbus Aubé, 1838, Gyrinus ovatus Klug, 1829, and Gyrinus paykulli Ochs, 1927b. Type specimens and diagnostic characters are illustrated for G. striatus Fabricius, G. striatus Olivier, G. ovatus Klug, G. racenisi and G. paykulli.
\end{abstract}

Key words. Coleoptera, Gyrinidae, nomenclature, homonymy, synonymy, new replacement name, lectotype designation, neotype designation

\section{Introduction}

When preparing the Gyrinidae section (HÁJEK \& FERY 2017) for the newest Palaearctic Catalogue of Coleoptera we found several nomenclatural inconsistencies and errors in the first version of the catalogue compiled by MAZzOLDI (2003). The corrections are now included in the new catalogue, but in the meantime several further nomenclatural problems came up which relate to both Palaearctic and
non-Palaearctic taxa. These problems are mainly homonymies, but also a few newly detected synonymies. For several of these problems we found a direct solution (e.g. replacement names), but others require proposals to be presented to the International Commission on Zoological Nomenclature for a ruling.

An especially complex situation is related to three nominal taxa from Brazil because here a misinterpretation 
of a species is combined with a subjective synonymy: Gyrinus ovatus Klug, 1829, Gyrinus ovatus sensu AuBÉ (1838b), and Gyrinus gibbus Aubé, 1838. Since, in this case, the historical background seems to us to be also quite interesting and taxonomic details can only rarely be found in the literature, we felt obliged to treat this case in more detail and provide numerous figures of the taxa involved.

Appeal: As already stated in FERY \& HÁJEK (2016: 646), all colleagues are encouraged to send their comments, communicate eventual mistakes and overlooked homonymies or synonymies. Doing so will support stability of the nomenclature and aid future applications to the International Commission on Zoological Nomenclature.

\section{Material and methods}

The following codens for collections which we have contacted for material are used in the text:

BMNH The Natural History Museum [former British Museum (Natural History)], London, UK (C. Taylor, M. Geiser);

CHF Collection H. Fery, Berlin, Germany;

IRSN Institut Royal des Sciences Naturelles, Brussels, Belgium (P. Limbourg);

MNBG Museum für Naturkunde Berlin, Germany (B. Jäger, J. Willers);

MNHN Muséum national d'Histoire naturelle, Paris, France (A. Mantilleri);

NMPC National Museum, Prague, Czech Republic (J. Hájek);

SMF Forschungsinstitut und Naturmuseum Senckenberg, Frankfurt -am-Main, Germany (A. Hastenpflug-Vesmanis);

ZMUK Zoological Museum der Universität Kiel, Germany (M. Kuhlmann).

Further abbreviations used in the text are: 'ICZN' for the 1999 edition of the 'International Code of Zoological Nomenclature', 'Commission' for the 'International Commission on Zoological Nomenclature' and 'hw' for handwriting. Authors' comments and translations are given in square brackets.

Antoine Mantilleri (MNHN) kindly placed Figures 6 and 8 to our disposal. The other photos were taken with a Canon EOS 550D digital camera attached to a SZX16 stereoscopic microscope. Helicon Focus 6.4.1 software was used to combine stacks of photos of the same object at different focal planes. Adobe Photoshop CS5 software was used to retouch micrographs.

Label texts of important specimens are cited literally and figured in part. Genitalia were studied in wet condition. In the headings of the sections we give the taxa involved with their original generic name and - if different - followed by their current generic assignment in square brackets.

\section{Systematics}

\section{Gyrinus australis Fabricius [Dineutus] and Gyrinus australis Brullé [Macrogyrus]}

History of classification. BRULlé (1835: 231) in his Histoire naturelle des insectes expressly treated the genus Gyrinus Geoffroy, 1762 as being composed of six subgenera (Gyrinus s. str.; Enhydrus Laporte, 1835 [not 1834]; Orectochilus Dejean, 1833; Porrorhynchus Laporte, 1835, Dineutes [= Dineutus Macleay, 1825] and Gyretes Brullé, 1835). However, in the species diagnoses following this statement, the author omitted the generic name and gave all species names only as binomina with the subgeneric name, e.g. 'Enhydrus australis. Br.' on p. 237. This somewhat contradicting approach was, however, either overlooked or neglected by subsequent authors, who considered these subgeneric names as generic names, and thus assumed different original combinations for the newly described species: Enhydrus australis instead of Gyrinus (Enhydrus) australis Brullé, 1835, and Gyretes aeneus instead of Gyrinus (Gyretes) aeneus Brullé, 1835 (see AuBé 1838b: $653,751)$.

However, we believe that the fact that Brullé used binomina in the species descriptions has no impact on the actual combination of the taxa; it is noteworthy, that BRULLÉ (1837: 52) still considered his Gyretes as a subgenus of $G y$ rinus. See a similar case in Dytiscidae (ZIMMERMANN 1921) and its solution (HÁJEK 2012, NiLSSON \& HÁJEK 2020).

Homonymy. Gyrinus australis Brullé, 1835: 237 (currently in Macrogyrus Régimbart, 1883a [not 1882]) is a junior primary homonym of $G$. australis Fabricius, 1775: 235 (currently in Dineutus), and thus Brullé's name is permanently invalid. At present both taxa are treated as different valid species. The fact that BRULLÉ (1835) published his species in the subgenus Enhydrus is irrelevant (see Article 57.4 of the ICZN).

Macrogyrus canaliculatus Régimbart, 1883a: 450 is a junior subjective synonym which could substitute Brullé's homonym. However, since AuBÉ (1838b: 785) treated Fabricius' species already in the genus Dineutus, and RÉGIMBART $(1892: 670,741)$ treated Brullé's species in the genus Macrogyrus - thus both long before the year 1900 - the specific name must not be replaced. According to Article 23.9.5 of the ICZN, this case must be '... referred to the Commission for a ruling under its plenary power' and we propose conservation of the junior homonym.

\section{Gyrinus australis Brullé [Macrogyrus] and Andogyrus colombicus australis Brinck [Macrogyrus]}

Homonymy. The genus Andogyrus Ochs, 1924 was relegated to a subgenus of Macrogyrus by GUSTAFSON \& Miller (2017). This is why Andogyrus colombicus australis Brinck, 1977: 263 became Macrogyrus (Andogyrus) colombicus australis, and thus a junior secondary homonym of Macrogyrus (Macrogyrus) australis (Brullé, 1835: 237) which originally was described with the generic name Gyrinus.

According to Article 60 of the ICZN, the junior homonym must be replaced. Since no available and potentially valid synonym exists, it must be replaced by a new substitute name. We propose the subspecific name brincki nom. nov. in the trinomen Macrogyrus (Andogyrus) colombicus brincki for the subspecies which so far was called Macrogyrus (Andogyrus) colombicus australis.

\section{Gyrinus dorsalis Gyllenhal and Gyrinus dorsalis Brullé [Gyretes]}

History of classification. Before dealing with this homonymy we want to present some remarks on the synonymy of 
G. dorsalis Gyllenhal, 1808: 142, and G. marinus Gyllenhal, 1808: 143. Gyllenhal described his G. dorsalis as a new species, but ends his description with the following 'Obs.' [= observation]: 'An modo var. immatura sequentis?' [= Or only an immature variation of the following?]. The author described Gyrinus marinus directly after $G$. dorsalis. STEPHENS (1829: 54) was the first who treated the two Gyllenhal names in the same work, where dorsalis was not treated as a valid specific name, but merely as 'dorsalis $\beta$ ' of G. marinus. This can be interpreted as 'var. $\beta$ ' even though Stephens did not expressly use the term 'var.' or any similar one. According to Article 24.2 of the ICZN, STEPHENS (1829) gave marinus precedence over dorsalis by acting as the First Reviser. Since then, the name dorsalis Gyllenhal was listed in the majority of publications either as an aberration, variety or synonym of G. marinus. Few people have used Gyllenhal's G. dorsalis as the valid name for this taxon instead of G. marinus, notably BAUDI (1889: 38 ) and then about 130 years subsequent to this was ÁdAm (1996: 61) (see NiLsSON 1998 for comments on Ádám's work).

Homonymy. Gyrinus dorsalis Brullé, 1837: 52 (currently in Gyretes) is a junior primary homonym of Gyrinus dorsalis Gyllenhal, 1808: 142 (currently a subjective synonym of Gyrinus marinus), and thus Brullé's name is permanently invalid. Gyrinus dorsalis Brullé was published in the subgenus Gyretes of genus Gyrinus. Already one year later AuBÉ (1838b: 747) elevated Gyretes to generic rank and treated Brullé's species in that genus. Additionally, RÉGIMBART (1892: 685) published a 'var. paraguensis' of dorsalis Brullé, which has to be treated of subspecific rank according to Article 45.6.4 of the ICZN. Later on, this taxon was treated as a subspecies by OcHs (1929: 90) and since then the name paraguensis has been in use as a valid subspecific name (e.g. COLPANI et al. 2014: 195).

Article 23.9.1 of the ICZN cannot be applied to conserve Brullé's name (1) because of ÁDAM's (1996) ill-considered action and (2) because we know of about 45 works published after Brullé's in which his taxon is included, with only about ten of them being published in the last 50 years. According to Article 23.9.3 of the ICZN, this case must be referred '.. . to the Commission for a ruling under the plenary power' and we propose conservation of the junior homonym.

Notes on infrasubspecific names. OCHS (1929: 90) published a name for a female form of Gyretes dorsalis: 'fa. q lugubris nov.' It might be argued that according to the first part of Article 45.6.4 of the ICZN this name has subspecific rank because it is published before 1961 and the term 'forma' is used (abbreviation 'fa.'). In this case the name lugubris Ochs would be an available name and could replace the name dorsalis Brullé.

However, 'female forms' (at least in Coleoptera) generally must be understood as polymorphic forms and these have infrasubspecific rank (see under infrasubspecific entity in the Glossary of the ICZN). Additionally, the content of Ochs' work 'unambiguously reveals that the name was proposed for an infrasubspecific entity' (Article 45.6.4 of the ICZN). This conclusion is due to the fact that
Ochs in his work did not only use names for female forms but also several names for subspecies. In particular, he elevated the var. paraguensis Régimbart of dorsalis Brullé to subspecific rank. Thus, it is clear that Ochs gave female forms a lower rank than subspecies and by this the rank of the name lugubris is infrasubspecific and accordingly unavailable. Therefore, it cannot replace the name dorsalis Brullé (see also Lingafelter \& NeARns (2013) and FERY (2020: 18)). Additionally, the name lugubris Brullé has never been 'adopted as the valid name of a species or subspecies nor was treated as a senior homonym' (Article 45.6.4.1 of the ICZN).

\section{$\uparrow$ Gyrinus dubius Giebel [†Paragyrinus] and Gyrinus dubius Wallis}

History of classification. GIEBEL (1856) published Gyrinus dubius by indication to fig. 6 of plate VII (an unnamed Coleoptera) in Brodie (1845). HANDLIRSCH (1906: 448) [not in 1908] introduced the generic name $\uparrow$ Paragyrinus [not OcHs 1924: 231] for Giebel's taxon, accompanied by the remark that it does not belong to Gyrinidae. NeL (1989: 328) listed it with doubtful assignment to family Gyrinidae. This fact has, however, no impact on the homonymy given below.

Homonymy. Gyrinus dubius Wallis, 1926: 93 is a junior primary homonym of the fossil $\dagger$ Gyrinus dubius Giebel, 1856: 56 (currently in $\uparrow$ Paragyrinus Handlirsch, 1906), and thus Wallis' name is permanently invalid.

No junior synonym of Gyrinus dubius Wallis is known which might substitute Wallis' name according to Article 60 of the ICZN. This is why we hereby replace the junior primary homonym of Gyrinus dubius Wallis, 1926 with Gyrinus suspectus nom. nov. The specific name is a Latin adjective in the nominative singular and is chosen because its meaning is more or less the same as 'dubius' [= doubtful]. A potential homonymy with the name Gyrinus dubius Motschulsky, 1853 can be disregarded because this name is a nomen nudum and thus unavailable.

\section{Gyrinus glaucus Klug [Orectogyrus] and Gyrinus glaucus Aubé [Macrogyrus]}

Homonymy. Gyrinus glaucus Aubé, 1838b: 657 (currently in subgenus Andogyrus of genus Macrogyrus) is a junior primary homonym of Gyrinus glaucus Klug, 1834: pl. XXXIV (currently in Orectogyrus Régimbart, 1884), and thus Aubé's name is permanently invalid. However, the two names apply to taxa not considered congeneric after 1899 and the junior homonym must not be automatically replaced (Article 23.9.5 of the ICZN).

- Klug's taxon was included by Brullé (1835: 238, footnote) in the subgenus Orectochilus of genus Gyrinus, in the genus Orectochilus by AuBÉ (1838b), and in the genus Orectogyrus since RÉGIMBART (1884).

- Aubé's taxon has been included in the genus Macrogyrus since RÉGIMBART (1883a), in the genus Andogyrus since OCHS (1924), and in Macrogyrus (Andogyrus) since GuSTAFSON \& MiLler (2017).

It follows that Macrogyrus borrei Régimbart, 1883a: 
436 - an available junior subjective synonym - cannot replace glaucus Aubé. According to Article 23.9.5 of the ICZN, this case must be '... referred to the Commission for a ruling under its plenary power' and we propose conservation of the junior homonym.

\section{Gyrinus marginatus Germar and Gyrinus marginatus Aubé [Aulonogyrus]}

History of classification. Germar (1823: 32) published his taxon as 'Gyrinus marginatus Eschscholtzii' and with the words 'Affinis Gyr. natatori, ...' and '... elytris distincte striato-punctatis, margine infero ferrugineis. Habitat in Livonia.' [= similar to Gyr. natator, ... elytra with distinct puncture lines, ventral margin [= epipleura] ferruginous. Occurring in Livonia]. (Livonia is a landscape in the Baltics which encompasses more or less the present southern Estonia and northern Latvia). Germar's name may be a nomen dubium, but it is an available name. It was dealt with in about 70 works and almost always treated either as aberration, variety, or synonym of $G$. natator (Linnaeus, 1758) (or of G. mergus Ahrens, 1812 which is currently treated as a junior subjective synonym of $G$. natator). Exceptions are SCHMIDT (1844: 12), who treated it as a valid name with author 'Eschs.' [= Eschscholtz] in a simple list of taxa, and DEJEAN (1833: 58, 1836: 66), who gave the name 'marginatus Eschsch.' as a synonym of G. marinus Gyllenhall in his catalogues.

Homonymy. Gyrinus marginatus Aubé, 1838b: 714 (currently in Aulonogyrus Motschulsky, 1853) is a junior primary homonym of G. marginatus Germar, 1823: 32, and thus Aubé's name is permanently invalid. Article 23.9 of the ICZN cannot be applied which would allow conserving Aubé's name and to suppress Germar's name as we know of about 35 works in which Aubé's name is used as valid with only 13 of them were published during the last 50 years.

We are convinced that the stability of the nomenclature is not threatened if the name of this rarely cited taxon is replaced be a new replacement name. In honour of Charles Aubé we propose the name Aulonogyrus charlesaubei nom. nov. for the species which was so far called Aulonogyrus marginatus (Aubé, 1838).

Notes. BRINCK (1955a: 381) gave the name 'Aulonogyrus capensis Wallengren, 1881: 15' in a 'synonymy list'. WALLENGREN (1881: 15) identified some Gyrinus as $G$. capensis Thunberg, 1781 (now in Aulonogyrus). BRINCK (1955: 381) after studying Wallengren's material found that these specimen(s) were misidentified specimen(s) of Aulonogyrus marginatus Aubé. It is therefore clear that WALLENGREN (1881) did not describe any new taxon and the name is thus unavailable.

\section{Gyrinus species described by OLIVIER (1792 and 1795)}

History of classification. Olivier (1792: 701 and 702) and Olivier (1795: 11 and 13) described three species of Gyrinus twice: Gyrinus striatus (currently in genus Aulonogyrus), Gyrinus longimanus (currently in Dineutus) and Gyrinus bidens (currently in Gyretes). The text of the descriptions of each species is almost identical in both publications. We are aware that such 'second descriptions' are not accepted as available new names by several colleagues. Since this problem is not regulated by the ICZN, we follow here the proceeding which is described in the Introduction of the World Catalogue of Dytiscidae (NILSSON \& HÁJEK 2020: 13; see also older versions of the Catalogue): A few authors like Aubé, Guignot, Régimbart and Sharp have in some of their works described the same species twice. The names produced in this way are both junior synonyms and junior homonyms; they are permanently invalid, but they are nevertheless available names, see Article 10.6 of the ICZN. In each such case two different names exist; however, such a junior synonym and homonym is only included in the Catalogue (and not accepted as redescription) if it explicitly is given as a new taxon and no reference is being made to the older description (not cited literally). A similar case in Gyrinidae are the species described by AUBÉ (1838a, 1838b), see FERY \& HÁJEK (2016: 648 and Table 1).

We want to add that Olivier (1795) in the Gyrinidae part (pp. 1-14) gave no hint on any species of the family described in his previous work. However, instead he referred to the work from 1791-1792 in several other species (e.g. Olivier 1795: 23 wrote: 'Dytiscus ciliatus ... Dict. ins. Dytique. no. 23. [= number of $D$. ciliatus in OLIVIER (1791)]').

Since no doubts exist about the identity of Gyrinus longimanus and G. bidens, and the names are not threatened by any other names we are not dealing with them in detail in the present paper and focus only on Gyrinus striatus (see below).

\section{Gyrinus striatus Fabricius [Aulonogyrus] and Gyrinus striatus Olivier [Aulonogyrus]} (Figs 1-3)

History of classification. FERY \& HÁJEK (2016: 652) declared G. striatus Olivier, 1795: 11 a junior primary homonym of $G$. striatus Fabricius, 1792: 203 (both currently in Aulonogyrus), and thus permanently invalid. Additionally, they did not consider designating a neotype necessary to clarify the identity of the taxon, but instead left $G$. striatus Olivier a nomen dubium. However, thus far it was widely overlooked that Olivier published Gyrinus striatus not only in 1795, but also previously in the year 1792 (p. 701) (see above). Since the name G. striatus Olivier, 1795 is a junior primary homonym of G. striatus Olivier, 1792 (as well as that of G. striatus Fabricius), the former name is permanently invalid and as such, we will not deal with it in detail in the following discussion.

Publication dates. FABricius (1792) as well as Olivier (1792) were published in the same year. According to EvenHuIs (1997) and BousQuet (2016), Olivier's work should be dated 1 October 1792, and Fabricius' work 22 December 1792. This would make the Fabrician name a junior primary homonym of Olivier's name. However, Y. Bousquet kindly communicated privately the following information: 'Subsequent to the publication of my " $\mathrm{Li}$ tteratura Coleopterologica" [BousQuET 2016] I found that Fabricius' book (Pars 1 and 2) was listed as being 


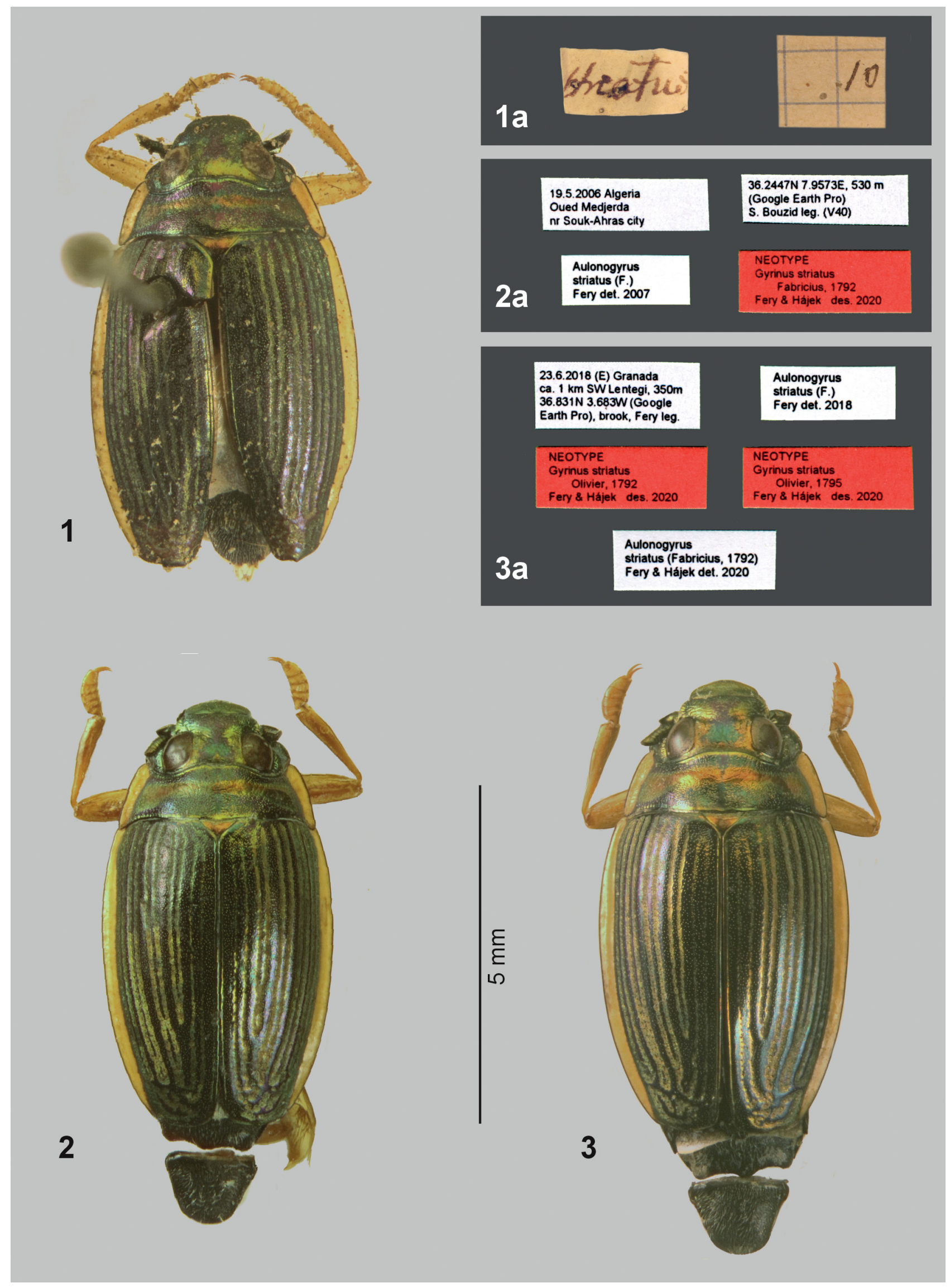

Figs 1-3: Habitus of Aulonogyrus striatus (Fabricius, 1792). 1 - specimen in the coll. Fabricius; 2 - neotype of Gyrinus striatus Fabricius 1792 ; 3 neotype of Gyrinus striatus Olivier, 1792 and of Gyrinus striatus Olivier, 1795. 1a-3a - respective labels. 
presented at the Leipzig Michaelismesse Book Fair of 1792 which according to EVENHUIS (2014) was held on $30 \mathrm{Sep}$ tember 1792.' We have checked EvENHUIs (2014: 4) and the Catalogue of the Michaelismesse (ANONYMOus 1792: 217) and confirm Bousquet's information. Thus - although the difference is only a single day - Gyrinus striatus Olivier, 1792 is a junior primary homonym of Gyrinus striatus Fabricius, 1792 and it is permanently invalid.

Notes on type material. Gyrinus striatus Fabricius: FABRICIUS (1792) wrote: 'Habitat in Barbariae aquis Mus. D. Desfontaines.' According to Horn et al. (1990a: 91; see also ZIMSEN 1964: 9) Desfontaines' collection should be preserved in the MNHN; however, no syntypes of this taxon were found in this museum (A. Mantilleri, pers. comm.). We have studied the sole specimen stored under this name in the collection Fabricius (ZMUK) - this is in fact an Aulonogyrus striatus (see Fig. 1 for the habitus and Fig. 1a for the label texts: 'striatus' [hw Fabricius] and '10' [hw ?]). However, there is no evidence that this specimen belongs to the syntype series or is the one Fabricius studied (see also OcHs 1927b: 40). The type locality of Fabricius's species is 'Barbaria', meaning more or less a region in northern Africa which includes today's Morocco, Algeria, Tunisia and Libya. Because both Aulonogyrus striatus and A. concinnus (Klug, 1834) occur in North Africa (see BRINCK 1955b: 98 and FrANCISCOLO 1979: 163), and Fabricius' description of his striatus does not allow a safe attribution to either one of these two species, this name is considered a nomen dubium.

Gyrinus striatus Olivier: OLIVIER (1792) described his taxon on the basis of material from the 'Cabinet de M. Gigot d'Orcy'. According to HorN et al. (1990b: 138) Gigot's collection should be preserved in the Muséum d'histoire naturelle, Genève; however, no syntypes of this taxon were found in this museum (I. Löbl, pers. comm.). The type locality of Olivier's species is Spain ('Il se trouve en Espagne, sur les eaux douces \& stagnantes'). It is quite clear that Gyrinus striatus Olivier denotes one of the two Aulonogyrus species known from Europe: A. striatus or $A$. concinnus - both have been recorded from Spain. However, the two species are externally very similar and the description of this taxon does not allow a safe attribution to one of the two species. This is why the two names striatus published by Olivier in 1792 and 1795 as well as the name striatus published by Fabricius in 1792 are nomina dubia. Designation of neotypes. As shown above, the identity of the species described by Fabricius and Olivier is not clear, and thus the stability of nomenclature is threatened. In accordance with Article 75.3 of the ICZN (1999) we state the need to clarify the identity of these species and hereby designate the neotype for each of the taxa under consideration. The identity of the taxa is in accordance with the description of Aulonogyrus striatus by HoLMEN (1987: $60 \mathrm{ff}$; see below as well for differentiating characters of $A$. concinnus).

Neotype of Gyrinus striatus Fabricius, 1792: The neotype is a male with the following label dates: '19.5.2006 Algeria, Oued Medjerda, nr Souk -Ahras city', '36.2447N 7.9573E, 530 m (Google Earth Pro), S. Bouzid leg. (V40)' [printed], 'Aulonogyrus striatus F., Fery det. 2007’ [printed].
We have added a red printed label 'Neotype, Gyrinus striatus Fabricius, 1792, Fery \& Hájek des. 2020’ (see Figs 2, 2a). The neotype (ex CHF) will be stored in the ZMUK.

Problems would come up, if it is found that the work of OLIVIER (1792) was published before that of FABRICIUS (1792). In this case Fabricius' name would become a junior homonym of Olivier's name, but the latter would be still a nomen dubium. In this case it will not be possible to apply Article 23.9 of the ICZN to give the Fabricius name precedence over that of Olivier because Olivier's name was used as valid after 1899, e.g. by HEYDEN et al. (1906: 123) and ZAITZEV (1908: 122) (both giving 1791 as the publishing date for Olivier's work). Furthermore, it cannot be excluded that in this case someone selects a specimen of Aulonogyrus concinnus from Spain for designating a neotype of this taxon and by this Klug's name would become a junior subjective synonym of Olivier's name. To avoid the possible confusion and destabilisation of the nomenclature, we also hereby designate a specimen from Spain as neotype for the taxon named Gyrinus striatus Olivier, 1792: 701.

Neotype of Gyrinus striatus Olivier, 1792 and G. striatus Olivier, 1795: The neotype is a male with the following label dates: '23.6.2018 (E) Granada, ca. 1 km SW Lentegi, 36.831N 3.683W, 350m, (Google Earth Pro), brook, Fery leg.' [printed], 'Aulonogyrus striatus F., Fery det. 2018' [printed]. We have added a red printed label 'Neotype, Gyrinus striatus Olivier, 1792, Fery \& Hájek des. 2020’ (see Figs 3, 3a). Additionally, we have added a printed label 'Aulonogyrus striatus (Fabricius, 1792), Fery \& Hájek det. 2020'. The neotype (ex CHF) will be stored in the MNBG. Additionally, we designate simultaneously the same specimen as neotype of Gyrinus striatus Olivier, 1795: 11 which makes both Olivier names objective synonyms. Accordingly, we have added another red printed label 'Neotype, Gyrinus striatus Olivier, 1795, Fery \& Hájek des. 2020’ (see Fig. 3a).

Gyrinus striatus Fabricius is now a senior subjective synonym of both G. striatus Olivier, 1792 syn. nov. and G. striatus Olivier, 1795 syn. nov.

\section{Gyrinus sulcatus Wiedemann [Enhydrus] and Gyrinus sulcatus Forsberg [Enhydrus]}

Homonymy. Gyrinus sulcatus Wiedemann, 1821 in WiEDEMANN \& GERMAR (1821: 119) and Gyrinus sulcatus Forsberg, 1821:314 are primary homonyms and subjective synonyms. The two taxa were described in the same year from Brazil and both names no doubt refer to the same species, the current Enhydrus sulcatus, because only a single species of Enhydrus is known which has 'sulci' on the elytra. It shall be noted that Gyrinus sulcatus Wiedemann is the type species of the genus Enhydrus.

The preface of volume 4 of the 'Magazin der Entomologie' ends with the date ' 1 . Jun. 1821' (which is not the publishing date). This volume is first given as published in the 'Allgemeiner Anzeiger der Deutschen' (1821, no. 234, p. 2517; available e.g. in Google Books; information communicated by Y. Bousquet) which was issued on August 29, 1821. Thus, the latter date must be accepted as the publishing date of Wiedemann's name.

The exact publishing date of volume 8 of the 'Nova Acta Regiae Societatis Scientiarium Upsaliensis' is unknown, and thus Forsberg's taxon must be dated December 31, 
1821. This is why Forsberg's name must be treated as a junior primary homonym of Wiedemann's name, and as such is permanently invalid.

\section{Gyrinus gibbus Aubé, Gyrinus ovatus Klug and related taxa}

History of classification. DEJEAN (1833: 59, 1836: 66) listed in his catalogues under the generic name Gyrinus a hitherto unknown Neotropical species as 'Ovatus. Klug. id. [= Brasilia]'. At first, this name appears to be a nomen nudum since Dejean gave no description at all. AuBÉ (1838b: 708 and 709) gave the description of two species: Gyrinus ovatus and Gyrinus gibbus (both currently in the subgenus Neogyrinus Hatch, 1926). For the former he referred to DEJEAN (1836: 66 [cited by Aubé as '1837: 66']) whilst he wrote 'Gyrinus GibBus Mihi.' and so claiming authorship for the latter species. On January 2nd, 1839 (only about three months after the publication of Aubé's oeuvre) an anonymous contemporary of Aubé gave a talk at the session of the Société Entomologique de France which is a critical review of Aubé's 'Species général' (the talk was published in the Annales de la Société - see AnONYmous 1839). This person must have had much experience in Hydradephaga and undoubtedly access to the collection of Dejean. We even suspect that it was Dejean himself who gave this talk at the Society. On p. 88 of this review it is stated: 'P. 708. Gyrinus ovatus. Il aurait fallu dire que le nom d'Ovatus avait été donné par Klug.' [ = It would have been necessary to say that the name Ovatus had been [already] given by Klug.] and 'P. 709. Gyrinus gibbus. Il aurait fallu dire que M. Dejean avait confondu cette espèce avec l'Ovatus.' [= It would have been necessary to say that M[onsieur] Dejean mixed up [or confused] this species with ovatus.]. To our knowledge, subsequently the contribution of this anonymous author was never paid attention to, the two names ovatus and gibbus were accepted as valid and their authorship generally attributed to Aubé (see below for two exceptions).

SHARP (1878: 117) introduced the species Gyrinus apicalis Sharp, 1878 and remarked at the end of his description: 'The species is allied to Gyrinus gibbus Aubé.' The synonymy of $G$. apicalis with $G$. gibbus was given by RÉGIMBART (1883b: 186, 187) with the following words: 'La description du $\mathrm{D}^{\mathrm{r}}$ Sharp a été faite sur des exemplaires entièrement roux pâle, en dessous, variété de beaucoup la plus répandue.' [= The description by Dr Sharp was based on specimens with entire light reddish ventral surface.]

OcHs (1953: 188) described a new species from Venezuela and gave it the name Gyrinus racenisi Ochs, 1953. He mentioned that his new species is closely related to $G$. ovatus Aubé, but also gave some differentiating characters. GUSTAFSON \& SHORT (2017: 493) showed in a detailed and convincing manner that the differences given by Ochs represent nothing more than 'intraspecific variation in elytral features' and thus G. racenisi must be treated a junior subjective synonym of $G$. ovatus Aubé.

About two years ago, we had noticed that already KLUG (1829: 3 ) described a new Gyrinus species under the specific name ovatus. Study of the syntypes of Klug's
G. ovatus - stored in the MNBG - revealed to our great surprise that these belong by no means to the same taxon as that described by Aubé as G. ovatus, but instead are conspecific with Aubé's G. gibbus. This synonymy is also supported by the text of a label which was mounted by Ochs on one of the syntypes of G. ovatus Klug (see Fig. 4a). With this revelation, the remarks in ANONYMOUS (1839: 88) also became much more plausible.

Finally, it was only recently that we became aware of the fact that AuBÉ (1838b: 708) had by no means the intention to describe a new species G. ovatus, but instead attributed the taxon he described to DEJEAN (1836: 66; see remark above). In turn, Dejean attributed the species 'Ovatus.' to 'Klug. id. [= Brasilia]' thus, relating to Klug's description from the year 1829. It may appear quite astonishing, but we must state that a name 'Gyrinus ovatus Aubé' has never been availably published. Misguided by mixed up specimens in Dejean's collection and being unaware of Klug's description Aubé gave nothing else than a description of a species which he believed to be meant in Dejean's catalogue (1836: 66). Whenever necessary, this name should be given as Gyrinus ovatus Klug sensu AuBé (1838b).

Additionally, we want to add the following annotations:

The name Gyrinus gibbus Aube is included in SHERBORN's 'Index animalium' (1926: 2688) as well as the name Gyrinus ovatus Klug (SHERBorn 1929: 4653). However, the name 'Gyrinus ovatus Aubé' is missing in Sherborn's index. Thus, most likely Sherborn was already aware that Aubé was not the author of the name Gyrinus ovatus, but instead Klug.

Klug's name was used in a very few works. Except those mentioned above, we know only of STURM (1843: 33) and a modern PhD-thesis for which, however, we have no evidence that it was availably published (GómEz LUTZ 2014: 39; undoubtedly, the author didn't know about the synonymy with $G$. gibbus because he had not studied the syntypes of Klug's species). Most interestingly, KLUG (1850: 14) himself used the name G. ovatus with author Aubé, possibly due to respect of the authority of Aubé or because he became aware of WHITE (1847: 46) who was the first to cite $G$. ovatus with author Aubé.

Results. The discovery of the name G. ovatus Klug and the finding that the name ovatus Aubé is only a sensu-name lead to the following results:

(1) The name Gyrinus racenisi Ochs, 1953 is the only available name for the species which thus far was known under the name G. ovatus Aubé and must be applied further on.

(2) The name Gyrinus ovatus Klug, 1829 must be used instead of its junior subjective synonym Gyrinus gibbus Aubé, 1838 syn. nov. Article 23.9 of the ICZN cannot be applied to give gibbus precedence over ovatus Klug because we found only 18 works published during the last 50 years in which Aubé's name was used as valid name.

Although the literature on $G$. racenisi (also under the name $G$. ovatus Aubé) and G. ovatus Klug (under the name G. gibbus) is not especially sparse, we are aware of only two publications in which characteristic features are figured. VIDAL SARMIENTo (1959: 239, fig. 21) illustrated 
the aedeagus of Gyrinus ovatus Klug sensu Aubé; however, the quality of this figure is rather poor and may fit both that of Klug's ovatus and G. racenisi as well. However, GUSTAFSON \& SHORT (2017) provided drawings of the male and female genitalia as well as excellent photos of the habitus of both species, which help to make reliable identifications.

Since the specimens studied by GUSTAFSON \& SHORT (2017) belong to non-typical material, we believe it important to here give information regarding the type material placed at our disposal. In particular, we provide photos of the habitus as well as that of male and female genitalia.

Considering the huge distribution areas of $G$. ovatus Klug, it cannot be excluded that its current definition includes more than one species (see the Discussion section under G. gibbus in GUSTAFSON \& SHORT 2017: 489). This is why we here designate a lectotype not only for this taxon, but also for its junior subjective synonyms $G$. gibbus and G. apicalis.

\section{Lectotype designations and diagnoses}

\section{Gyrinus ovatus Klug, 1829}

(Figs 4-6, 9, 12-13, 15)

Gyrinus ovatus Klug, 1829: 3 (original description; type locality: 'Süd -Brasilien').

Gyrinus gibbus Aubé, 1838b: 709 (original description; type locality 'Brésil'); RÉGIMBART (1883b): 186 (redescription); RÉGIMBART (1903): 74 (new records); OcHs (1924): 230 (redescription); syn. nov.

Gyrinus (Neogyrinus) gibbus: OCHS (1935): 128 (subgeneric association, redescription); OcHS (1949): 277 (redescription); OcHs (1954): 132 (redescription); COLPANI et al. (2014): 188 (distribution, literature); GUSTAFSON \& SHORT (2017): 484 (redescription, Venezuela).

Gyrinus apicalis Sharp, 1878: 117 (original description; type locality: 'Santa Cruz' [Brazil]); RÉGIMBART (1883b): 186 (synonymy with $G$. gibbus); syn. nov.

Type material. Gyrinus ovatus: The syntype series of G. ovatus Klug found in the MNBG consists of five specimens arranged in a single row. The first syntype in this row is the best preserved male and we designate it hereby as lectotype of Gyrinus ovatus Klug, 1829 (Fig. 4): LeCTOTYPE: 今, '10340' [printed], 'Sello. 1.' [green, handwriting unknown; text most probably meaning 'Sellow leg.'], 'ovatus N.' [handwriting Klug: the 'N.' means 'new'], 'Gyrinus gibbus Aubé, det. Ochs 1937' [handwriting Ochs], 'Hist. Coll. (Coleoptera), Nr. 10340, Gyrinus ovatus N., Brasil Sellow, Zool. Mus. Berlin' [green, printed], 'Lectotype, Gyrinus ovatus KLUG, 1829, Fery \& Hájek des. 2020’ [red, printed] (see Fig. 4a). PARA-

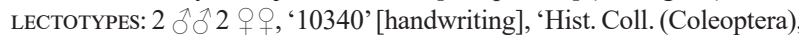
Nr. 10340, Gyrinus ovatus N., Brasil Sellow, Zool. Mus. Berlin’ [green, printed]; one male with additional 'ovatus ? Brasil.' [handwriting Ochs] (MNBG). All four paralectotypes are provided with a respective red label. Originally, all specimens were pinned, but are now glued on cards; the original pins have been kept.

Gyrinus gibbus: According to the text in AUBÉ (1838b), the author has studied more than a single specimen. In the collection Oberthür (MNHN) exists one specimen which can be reliably identified as one of the syntypes and which we designate hereby as the lectotype of $G$. gibbus Aubé, 1838 (Fig. 6): LeCtotyPe: ふ̄' 'gibbus. Aubé., ovatus var. m [= mihi], . in Brasil. merid.' [green, hw Dejean], 'Ex Musaeo, Dejean' [printed], 'Muséum Paris, 1952, coll. R. Oberthür' [printed], 'Type' [red, printed], 'Syntype' [red, printed], 'Syntype, Gyrinus, gibbus Aubé, 1838 ' [printed], 'MNHN, EC9691' [printed], 'Lectotype, Gyrinus gibbus Aubé, 1838, Fery \& Hájek des. 2020’ [red, printed], ‘Gyrinus ovatus Klug, 1829, Fery \& Hájek det., 2020’ [printed] (see Fig. 6a). It is noteworthy that on the first label the specific name ' gibbus' with author Aubé is given. Thus, we must assume that Dejean made this label after publication of AuBÉ's 'Species général' (1838b). The words 'ovatus var. m[ihi]' may be a hint on the statement in ANONYmous (1839: 88) that the material in Dejean's collection was mixed up (see above).

Gyrinus apicalis: The syntypes of G. apicalis Sharp, 1878 are stored in the IRSN. We designate hereby one male of these syntypes as lectotype (Fig. 5): Leсtотуре: đo, 'St. Cruz, C. v. Volxem, det. Sharp' [black margin, hw Severin], '7920' [printed], 'Gyrinus apicalis, Ind. typ., D.S.' [hw Sharp], 'Syntype' [printed, red on white label, with black margin], 'Coll. R. I. Sc. N. B.' [printed, brown label], 'Lectotype, Gyrinus apicalis Sharp, 1878, Fery \& Hájek des. 2020' [red, printed], 'Gyrinus ovatus Klug, 1829, Fery \& Hájek det. 2020’ [printed] (see Fig. 5a). 14 additional specimens are stored in the IRSN which might belong to the original syntype series. These are all from Brazil and with collecting data as cited by SHARP (1878): St. Cruz, Rio Janeiro, Entre Rios and Porto Novo. We refrain, however, from declaring them paralectotypes because they are not labelled by Sharp, and and thus we are not sure if they belong in fact to the syntype series..

Additional material studied. BRAZIL: 1 , 'Brazil, Wehncke' (NMPC). 1 ㅇ, 'Brésil, coll. Régimb.' [hw Severin], 'G. apicalis Shp' [hw Régimbart], 'Coll. Séverin, Détermin. Régimb. 1890', '11111'; 1 9, 'Brésil, coll. Régimb.' [hw Severin], 'Coll. Séverin, Détermin. Régimb. 1890', '11114'; 1 specimen (abdomen lacking), 'Brésil, Coll. Chevrolat, Det. Régimb. [18]82’ [hw Severin], '7919'. COLOMBIA: 1 q, 'Colombie, Lansberge, Det. Sharp' [hw Severin], '7921'. VENEZUELA: $1 \hat{\jmath}$, 'Venezuela, coll. Chevrolat, Det. Régimb. [18]82' [hw Severin], 'Gyrinus semistriatus (Chv), Venezuela D. Rojas' [hw Chevrolat], '7921' [printed]; aedeagus lacking. Without locality data: 1 , 'Coll. Chevrolat., Det Régimb - [18]90' [hw Severin], 'rotundipennis, Chevr. i. litt.' [hw Severin], '11114' (all IRSN). Six further specimens from the IRSN without locality data shall not be listed in detail.

Comments. The type locality of G. ovatus Klug is 'Süd -Brasilien' [= southern Brazil]. The species was published in a price-list of duplicates present in the Berlin Museum and offered for sale. Nevertheless, the work contains descriptive notes on many of the taxa included and several of them are marked by an 'n.' as new to science. On page 3 of this work starts a list with specimens from southern Brazil and here is given: 'Gyrinus ovatus n. convexus, subtus testaceus, supra fusco-aeneus, elytris, dorso obsolete, punctatostriatus, apice truncatis ( $G$. natatore minor.)' [= Gyrinus ovatus n. convex, venter testaceous, upper surface with blackish metallic sheen, elytra with punctures lines, obsolete on disc, apex truncate (smaller than G. natator)]. The collector of the syntype series was Friedrich Sellow (also spelt 'Sello'), a German gardener and naturalist who travelled to Brazil and Uruguay between 1814 and 1831. For more information see HACKETHAL (1995) and ZISCHLER et al. (2013). There is no doubt that Dejean had good relations with German entomologists and that he and Klug likewise exchanged material (see KLUG 1829: 1). We assume that Dejean had received material of G. ovatus from Klug in the early 19 th century.

The type locality of G. gibbus Aubé is 'Brésil'. In AuBÉ (1838b: 709) the description of G. gibbus is given directly after the description of his G. ovatus. The texts of the descriptions are more than $90 \%$ identical, but $G$. gibbus was described as having the external posterolateral angles of the elytra broadly rounded while these angles are described as distinct and not rounded at all in G. ovatus Klug sensu AuBÉ (1838b).

The type locality of G. apicalis SHarp is 'Santa Cruz' [Brazil] and the syntypes were collected by van Volxem. Gustafson \& SHORT (2017: 484) assumed that the type locality is 'likely Santa Cruz do Sol, Brazil' 


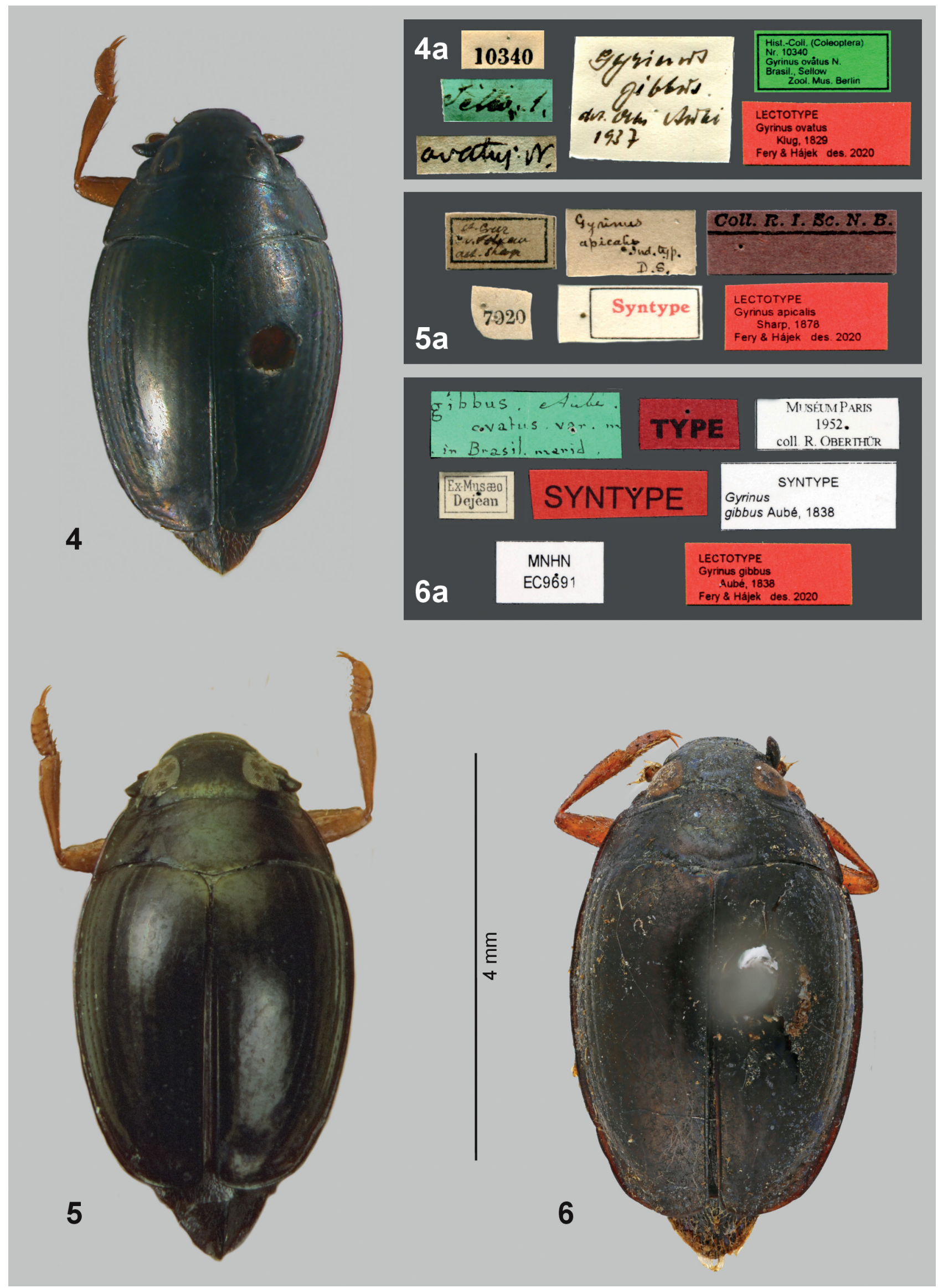

Figs 4-6: Habitus of Gyrinus lectotypes. 4 - Gyrinus ovatus Klug, 1829; 5 - Gyrinus apicalis Sharp, 1878; 6 - Gyrinus gibbus Aubé, 1838. 4a-6a respective labels. 
which is situated more than $1100 \mathrm{~km} \mathrm{SW}$ of Rio de Janeiro. According to Preudhomme De Borre (1886: 103), van Volxem collected in the years 1872-1873 'aux provinces brésiliennes de Rio Janeiro et Minas Geraes' (and in Argentina). This is why we believe that the type locality of G. apicalis is another Santa Cruz which is located about $20 \mathrm{~km} \mathrm{~W}$ of Rio de Janeiro, ca. 22.93S 43.68W.

Diagnosis. We refrain from giving a complete redescription of G. ovatus Klug and refer instead to the redescriptions in Aubé (1838b: 709; under G. gibbus) and a very detailed redescription in Gustafson \& SHORT (2017:

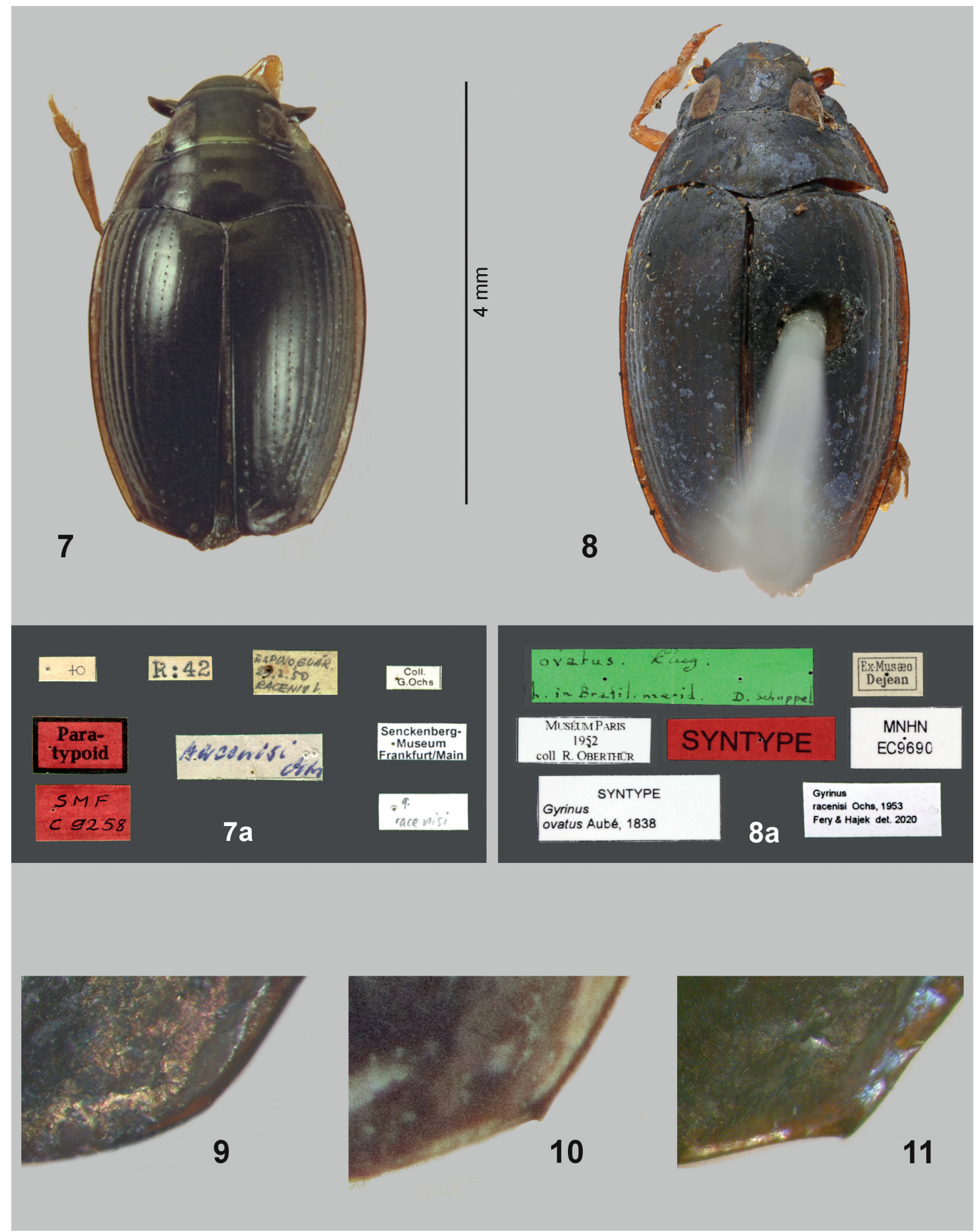

Figs 7-11: 7-8-Gyrinus racenisi Ochs, 1953: 7 - habitus of 9 paratype; 8 - specimen of G. ovatus sensu AuBÉ (1838b) in the coll. Dejean. 7a-8a respective labels. 9-11 - apical part of right elytron of: 9 - G. ovatus Klug, 1829 (lectotype); 10 - G. racenisi ( 9 paratype); 11 - G. racenisi (Paraguay, Capiatá, Rio Paraguay). 
484; also under G. gibbus). Nevertheless, it seems to be important to give at least some notes on the most characteristic features of the species - the apical part of the elytra and the male and female genitalia. The posterior margin of the elytra (Figs 4-6 and 9) is more or less evenly curved over its entire length. Traces of a corner at the epipleural angle (where a denticle is present in $G$. racenisi, see Figs 7-8, 10-11) can be found in several specimens (sometimes a little more distinct than in Fig. 9), but not forming a distinct corner or a denticle. The shape of the aedeagus is given in Figs 12-13; the apical part of the median lobe is nearly parallel-sided in the lectotype of G. ovatus Klug (Fig. 12), but it is slightly broadened in the lectotype of G. apicalis (Fig. 13). The female genitalia are given in Fig. 15. We found that the latter are somewhat variable and a reliable determination should be supported by other characters.

Distribution. Argentina, Bolivia, Brazil, Colombia, Costa Rica, Ecuador, French Guiana, Guyana, Paraguay, Peru, Uruguay, Venezuela (ColPani et al. 2014: 188), ‘... potentially as far as Mexico...' (GUSTAFSON \& SHORT 2017: 489).

\section{Gyrinus racenisi Ochs, 1953, status reinstituted}

(Figs 7-8, 10-11, 14, 16)

Gyrinus (Neogyrinus) racenisi Ochs, 1953: 188 (original description); GUSTAFSON \& SHORT (2017): 493 (in synonymy).

Gyrinus ovatus Dejean: AuBé (1838b): 708 (description; 'Brésil et Cayenne').

Gyrinus ovatus Aubé: RÉGIMBART (1883b): 185 (description); OCHS (1924): 230 (description).

Gyrinus (Neogyrinus) ovatus Aubé: Ochs (1935): 126 (subgenus association, description); OCHS (1949): 276 (description); OCHS (1954): 132 (description); COLPANI et al. (2014): 189 (distribution, literature); GUSTAFSON \& SHORT (2017): 493 (description, Venezuela).

Type material. We were unable to study the holotype (a female) of this taxon which - according to OcHs (1953) - is stored in the 'Museo de Biologia de la Universidad Central de Venezuela'. We studied, however, one female paratype from SMF (Fig. 7): ' $Q$ ', 'R:42' [printed], 'Espino, Guàr., 29.3.[19]50, Racenis L.' [hw ?], 'Coll. G. Ochs' [printed], 'Paratypoid' [red, printed], on reverse 'SMF, C 9258' [hw ?], 'racenisi Ochs' [hw Ochs], 'Senckenberg-Museum, Frankfurt/Main' [printed], on reverse 'G. racenisi' [hw ?] (see Fig. 7a).

Additional material studied. BRAZIL: A specimen which so far was treated as a syntype of ' $G$. ovatus AuBÉ' is stored in the MNHN (Fig. 8): 'ovatus. Klug, h. [= habitat] in Brasil. merid. D. Schuppel' [green, hw Dejean], 'Ex Musaeo, Dejean' [printed], 'Muséum Paris, 1952, coll. R. Oberthür' [printed], 'Syntype' [red, printed], 'Syntype, Gyrinus ovatus Aubé, 1838' [printed], 'MNHN, EC9690' [printed]; we have added a label 'Gyrinus racenisi Ochs, 1953, Fery \& Hájek det. 2020' [printed] (see Fig. 8a). 1 §ै, ‘ ’, 'St. Cruz, C. v. Volxem, Det. Sharp' [hw Severin], ' 7 , Gyrinus ovatus Aubé, D.S. [= David Sharp], Santa Cruz. 10-17. 7. [18]72' [hw Sharp], '7919'; 1 +, ‘ ' ', 'St. Cruz, C. v. Volxem, Det. Sharp' [hw Severin], 'R. Mouchamps vid., 1955, Gyrinus ovatus Aubé.'; $2 \hat{\partial}$, same labels as the above, but without Sharp's handwritten label; 1 specimen in very bad condition, abdomen lacking, 'Rio Janeiro, C. v. Volxem, Det. Sharp' [hw Severin], '7920', 'R. Mouchamps det., 1955, Gyrinus ovatus Aubé'. PARAGUAY: 1 ก, 'Paraguay, Capiata, Rio Paraguay, xii-1936', 'R. Mus. Hist. Nat., Belg. I. G. 11.241', 'R. Mouchamps det., 1955, Gyrinus ovatus Aubé'. URUGUAY: 1 + 'Montevideo, coll. Chevrolat, Det. Régimb[art]. [18]82' [hw Severin], 'Gyrinus ovatus Aubé/ ${ }^{\circ}$, Dj Cat 3 p. 66 [= Dejean Catalogue 3, p. 66], Brasilia Montevideo.' [hw Chevrolat], 'Gyri margine-striatus Chv, Mvid [?] a....[four illegible letters]' [hw Régimbart] (all IRSN).
Diagnosis. As for G. ovatus Klug, we refrain from giving a complete redescription of $G$. racenisi and refer instead to the (re)descriptions in OCHS (1953: 188), AubÉ (1838b: 708; under G. ovatus) and GUSTAFSON \& SHORT (2017: 494; under G. ovatus Aubé). However, we believe it is necessary to give some notes and illustrations of the apical part of the elytra and the male and female genitalia which - as in G. ovatus Klug - are rather characteristic.

The posterior margin of the elytra is broadly rounded at the sutural angle, more laterally straight (or even slightly sinuate) and here forming a distinct corner at the epipleural angle sometimes with a denticle (Fig. 10). This corner or denticle is in most specimens studied quite small, but in the specimen from Paraguay it is very distinct (Fig. 11). The shape of the aedeagus is given in Fig. 14; it is conspicuously broadened apically. The female genitalia are given in Fig. 16.

Distribution. Argentina, Bolivia, Brazil, Ecuador, French Guiana, Guatemala, Mexico, Paraguay, Peru, Uruguay, Venezuela (COLPANi et al. 2014: 189, GUSTAFSON \& SHORT 2017: 497; all under 'G. ovatus Aubé').

\section{Gyrinus bicolor Fabricius and Gyrinus paykulli Ochs (Figs 17-19)}

History of classification. The status of the name Gyrinus bicolor Fabricius, 1787: 194 has been disputed for a long time as has the identity of the taxon as well. The text of the original description is ' $G[y$ rinus $]$. niger subtus ferrugineus, pedibus posticis compressis. Habitat in Sueciae aquis Prof. Leske. Maior praecedente $[=G$. natator $]$ totus supra niger, subtus ferrugineus. Pedes postice valde compressi.' The main information contained in this description is that the specimen(s) studied have a black dorsal surface and a ferruginous ventral surface. In FABRICIUS (1792: 202) the former text is more or less reproduced and gives no additional information.

We refrain from giving a thorough presentation of the history of the different developments and interpretations of Fabricius' species, but reproduce 'Notes on synonymy' given by HoLMEN $(1987: 56,57)$ which contain essential historical details and interpretations (see also BALFOURBROWNE 1950: 350 ff.). In particular, we believe that Holmen's assumption that G. bicolor might be conspecific with Gyrinus urinator Illiger, 1807 should be considered accurate. 'Fabricius (1787) originally described G. bicolor on specimen(s) of same size as natator, with a reddish ventral side, and collected in Sweden by Leske. The type material has not since been discovered, and the identity of the species remains uncertain. The only Fennoscandian species which normally has a reddish ventral side is the small G. minutus described by Fabricius (1798). Paykull (1798) interpreted Fabricius' description as the species now known as G. paykulli Ochs. A few years later Fabricius (1801) added to the description that the species is elongate, but this character may have been taken from Paykull's description. Other authors have considered Fabricius'species to be identical with G. natator (L.), G. substriatus Stph. or G. caspius Mén. All these may, like 


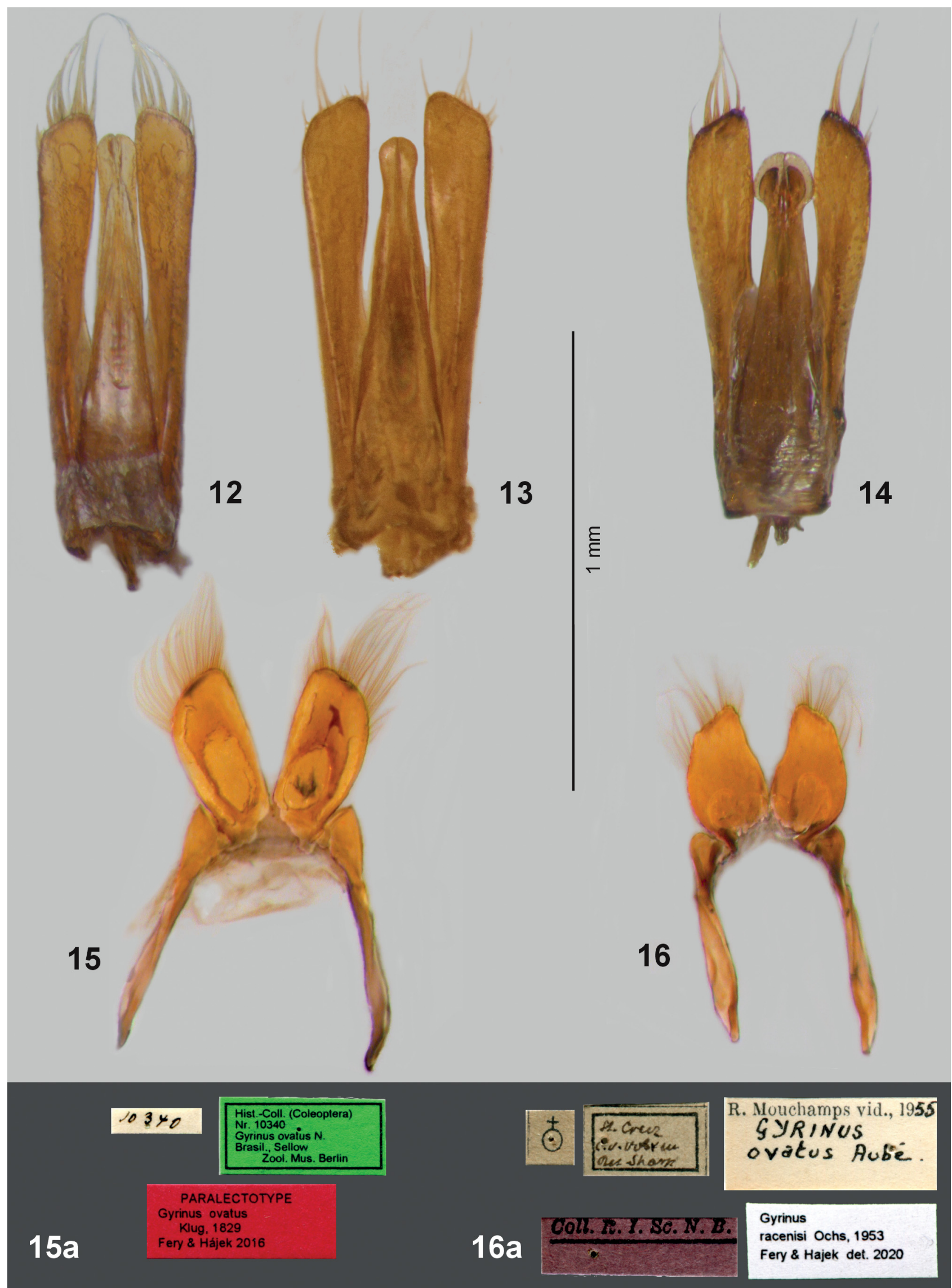

Figs 12-16: Genitalia of Gyrinus species. 12-14 - aedeagus of: 12 - G. ovatus Klug, 1829 (lectotype); 13 - the same (lectotype of Gyrinus apicalis Sharp, 1878); 14 - Gyrinus racenisi Ochs, 1953 (Brazil, Santa Cruz). 15-16 - female genitalia of: 15 - G. ovatus Klug (paralectotype); 16 - G. racenisi (Brazil, Santa Cruz). 15a-16a - respective labels. 


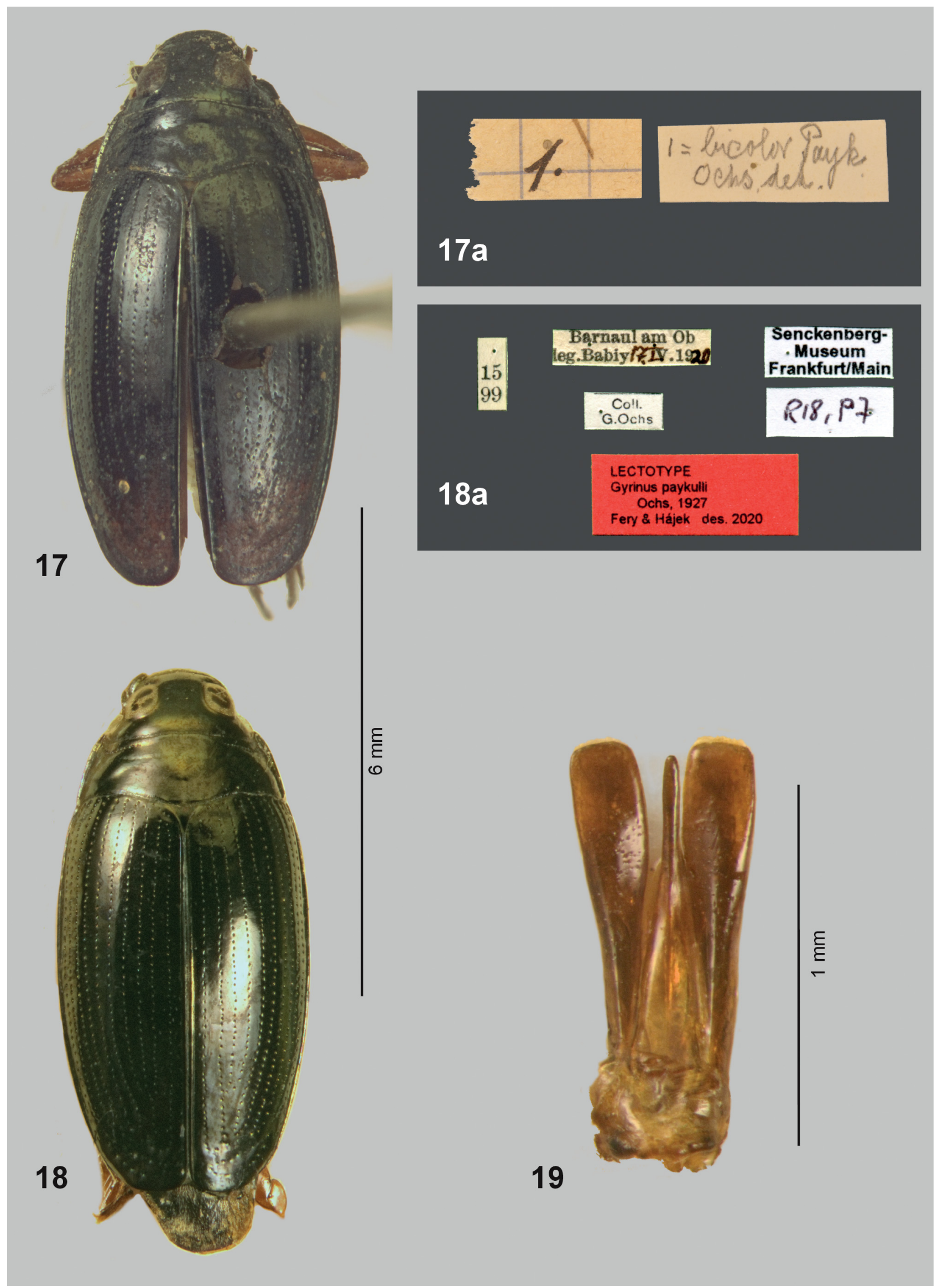

Figs 17-19: Gyrinus paykulli Ochs, 1927. 17 - specimen of Gyrinus 'bicolor' in coll. Fabricius; 18 - lectotype of Gyrinus paykulli. 17a-18a - respective labels. 19 - aedeagus (lectotype of G. paykulli). 
paykulli, have parts of the ventral side reddish. Anyway, both paykulli and natator are present in Fabricius' collection, but under the name 'natator'. There is also the possibility that the original specimens of bicolor were wrongly interpreted as Swedish, as Leske also worked on many Italian insects. If this is the case, the specimens might well be conspecific with $\boldsymbol{G}$. urinator Ill. This is the European species which normally best fits the original description of bicolor, and it is very common in the Mediterranean area. Olivier (1795), Paykull (1798) and Latreille (1807) never originally described species by the name Gyrinus bicolor, as stated by many authors; each of these authors merely interpreted Fabricius' description as one of the above mentioned species.'

We want to add that Holmen did not study the material in Fabricius' collection, but took information in part from OcHs (1927b: 37). In this work further information can be found regarding the interpretation of the taxon G. bicolor during the last centuries. Ultimately, OCHS (1927b: p. 39) concluded: 'G. bicolor F. ist ... im Katalog als unidentifizierte Art zu vermerken.' [ = In the catalogue G. bicolor F. must be declared as an unidentified species.]. This means that $G$. bicolor is a nomen dubium, an opinion with which we agree. OcHs (1927b) did not mean the Fabrician $G$. bicolor, but the species which PAYKULL (1798) interpreted as being that of Fabricius and which is often cited as 'Gyrinus bicolor Paykull' (also with 'sensu Paykull' or 'sensu auctores').

Notes on the type material. In order to clear the identity of Gyrinus bicolor Fabricius, we have studied the specimens which stand in the Fabricius' collection in a box under the joint name 'natator' (hw Fabricius). There is one male with the label 'natator L.' and another male with 'bicolor Payk.' (Fig. 17a), both labelled by Ochs. The former is not a G. paykulli, but the latter is in fact this species (Fig. 17). It lacks all abdominal ventrites including the genitalia. FABRICIUS (1787: 194) described the ventral surface of $G$. bicolor as 'subtus ferrugineus' which means more or less 'entirely reddish brown'. However, the ventral surface of the specimen is largely blackish; the only reddish brown aspects being the: mouthparts, gula, hypomeron, epipleura of elytra, mesoventrite shortly between procoxae, metacoxal plates near end of metaventral processes, metaventral processes distally, all legs including trochanter and proand mesocoxae. The ventral surface may be somewhat darkened by aging and it is quite dirty, covered in part with fungal mycelia. We have added a printed label 'Gyrinus paykulli Ochs, Fery det. 2020'.

All of these observations show that there is no direct evidence that either of the two specimens was studied by Fabricius or belong to what he named G. bicolor. We also sent a request to the Dublin Museum where the coll. Leske (or parts of) is stored. Unfortunately, no Gyrinidae specimens could be found and we must conclude that the syntypes of $G$. bicolor are lost or at least not identifiable as such. We refrain from fixing the identity of G. bicolor by designating a neotype, because no matter from which species a neotype is chosen - G. paykulli or G. urinator or even any other species - the stability of the nomenclature would be considerably threatened as the current name of each species in question would fall into synonymy with the name $G$. bicolor.

It is, however, necessary to designate a lectotype of Gyrinus paykulli Ochs, $1927 \mathrm{~b}$, for which a name bearing type has never been properly defined. The specific name is available, nevertheless, because before 2000 it was not obligatory to explicitly designate syntypes or a holotype for a newly described taxon in the original work. It is a widely accepted valid name - for instance we know more than 200 works published in the last 50 years in which it is used. On the other hand, it is considered a junior synonym of G. bicolor by F. BALFOUR-Browne (1950, 1953), FrIDAY (1988; a widely distributed work and still in use by many entomologists), ANGus (1989), and ÁDÁM (1996). However, we suspect that not all authors who used the name $G$. bicolor meant the species which at present is called G. paykulli; e.g. MAzzoLDI (1995) considered $G$. bicolor either a synonym of $G$. minutus Fabricius, 1798, G. caspius Ménétriés, 1832, or G. paykulli (all with question mark).

We therefore fix the identity of G. paykulli. The normal procedure would be to designate a lectotype from among the material which Ochs used when he published the new name. However, OcHs (1927b) did not explicitly indicate any material in his work. There is, however, an indirect hint at the material in his work: 'Ich schlage daher vor, die bisher als bicolor Payk. bezeichnete Spezies in Zukunft als G. Paykulli nom. nov. zu führen, da Paykull die erste unzweideutige Beschreibung davon gegeben hat; ...' [= This is why I propose to classify in the future as $G$. Paykulli nom. nov. the species, which so far was called bicolor Payk., because Paykull was the first to give an unambiguous description; ....].

According to Articles 72.4.1 ('The type series of a nominal species-group taxon consists of all the specimens included by the author in the new nominal taxon (whether directly or by bibliographic reference), ...') and Article 74.4.1.1 of the ICZN ('For a nominal species or subspecies established before 2000, any evidence, published or unpublished, may be taken into account to determine what specimens constitute the type series.') one might argue that formally all specimens in the collections of all authors and collectors standing under the name G. bicolor 'Paykull' belong to an enormous quantity of syntypes. However, we consider only those specimens as syntypes which were studied by Ochs personally. Definitely, among these syntypes are those which Ochs in the year 1927 preserved in his own collection.

The senior author has studied all 78 specimens which stand under G. paykulli in the Ochs collection (SMF). Among them, there is a series of 10 specimens from Barnaul (Russia, Siberia). These specimens are mentioned (under 'G. bicolor Payk.') in OcHs (1927a: 48). Thus, there is no doubt that Ochs had studied these specimens and that they belong to the syntype series. From these syntypes stored in the SMF we designate here the lectotype of Gyrinus paykulli Ochs and consider the other nine specimens as paralectotypes: 
LECTOTYPE: $\delta$ (Fig. 18) with the following label data: '15 99' [collection number?] [printed], 'Barnaul am Ob, leg. Babiy 17.IV.1920’ [printed, date hw in part], 'coll. G. Ochs' [printed], 'Senckenberg-Museum, Frankfurt/ Main' [printed], on reverse 'R18, P7' [hw ?], 'Lectotype, Gyrinus paykulli Ochs, 1927, Fery \& Hájek des. 2020’ [red, printed] (see Fig. 18a). The aedeagus (Fig. 19) is glued behind the specimen, preparation most probably by Ochs. PARALECTOTYPES: 2 specimens with same label data except collection numbers ' 15 89' and ' 16 03'; 4 specimens with same label data except date '27.IV.1919' and printed collection numbers ' 1831 ', ' 1832 ', ' 1834 ' and ' 1835 '; 1 specimen with same label data except date '18.IV.1920' and printed collection numbers '15 32'; 2 specimens with label data 'Sibirien., Barnaul a. Ob, 21.4.[19]20 Babiy' [printed except date], 'G. Ochs det.' [printed], 'ex Coll. G. Ochs' [printed], 'SenckenbergMuseum, Frankfurt/Main' [printed]. All nine paralectotypes are provided with the respective red paralectotype label. Possible other paralectotypes in the collection Ochs are not labelled by us as such.

\section{Notes on the lectotype designation of Dineutus (Porrorhynchus) landaisi latilimbus Ochs}

GuSTAFSON \& Miller (2016: 688) claimed to have designated the lectotype of Dineutus (Porrorhynchus) landaisi latilimbus Ochs, 1926 (now in the genus Porrorhynchus) and listed also a paralectotype, both stored in the SMF. In his description Ochs (1926: 193) wrote: 'Typus von Hainan 10.-25. III. 1909 (H. Schoede) im Berliner Zoolog-Museum.' ' = 'type (singular!) from Hainan ... in the Berlin Zoological Museum' (now MNBG)]. In contrast he wrote e.g. 'Typen in meiner Sammlung' [= 'types (plural!) in my collection'] under Dineutus (Porrorhynchus) mjobergi Ochs, 1926: 193 (not mjöbergi as given in GUSTAFSON \& MiLler 2016: 691).

Ochs' 'Typus' is in fact stored in the MNBG and bears the following labels: ' 0 ', 'China, Insel Hainan, 10.-25.III. [19]09, H. Schoede S.G.' [printed, except date], '102966' [hw ?; a historical museum's number], 'P. Landaisi, subsp. latilimbus, Type $\widehat{\sigma}$ Ochs' [hw Ochs]. There is also a female specimen in the MNBG with similar labels (except the historical number label and female gender symbols).

According to Article 73.1.1 of the ICZN the 'Typus' is the holotype of Dineutus (Porrorhynchus) landaisi latilimbus Ochs, 1926, and the lectotype designation by GUSTAFSON \& MiLleR (2016) is invalid. The female specimen is a paratype and we consider also the two specimens in the SMF as paratypes. We have mounted to the holotype a red label 'Holotype, Dineutus (Porrorhynchus) landaisi latilimbus Ochs, 1926, Fery \& Hájek 2020' and will advise the staff of the SMF to mount a respective red paratype label.

\section{Acknowledgements}

We thank all curators listed in the section Material and methods for the loan of or permission to study specimens. Thanks are also due to the following colleagues for supporting us by translations of Latin texts and/or other valuable information and help: R. B. Angus (BMNH), J. Bezděk (Brno, Czech Republic), S. Bouzid (Annaba, Algeria), P. Kment (NMPC), I. Löbl (Genève, Switzerland), M. Manuel (Paris, France), E. Orduña (El Pont de Suert, Spain), P. Viscardi (Dublin, Ireland) and F. Welter-Schultes (Göttingen, Germany). We are obliged to Y. Bousquet (Ottawa, Canada) and G. T. Gustafson (Flagstaff, USA) for critical comments on the manuscript. The work of J. Hájek was supported by the Ministry of Culture of the Czech Republic (DKRVO 2019-2023/5.I.c, National Museum, 00023272).

\section{References}

ÁDÁM L. 1996: A check-list of the Hungarian caraboid beetles (Coleoptera). Folia Entomologica Hungarica 57: 5-64.

AHLWARTH K. 1910: Pars 21. Gyrinidae. In: SCHENKLING S. (ed.): Coleopterorum Catalogus. W. Junk, Berlin, 42 pp.

ANGUS R. B. 1989: A tale of two Baedeckers - Öland and Hamburg in the springtime. Balfour-Browne Club Newsletter 45: 1-3.

ANONYMOUS 1792: Allgemeines Verzeichniß der Bücher, welche in der Frankfurter und Leipziger Michaelismesse des 1792 Jahre entweder neu gedruckt, oder sonst verbessert, wieder aufgelegt worden sind, auch ins künftige noch herauskommen sollen. Weidmannsche Buchhandlung, Leipzig, pp. 199-296.

ANONYMOUS 1839: Réflexions critiques sur le Species des Hydrocanthares et des Gyriniens de M. le Docteur Ch. Aubé. Annales de la Société Entomologique de France 8: 67-90 [+ Erratum p. 1xxix].

AUBÉ C. 1836-1838a: Iconographie et histoire naturelle des coléoptères d'Europe. Tome Cinquième. Hydrocanthares. Méquignon-Marvis, Paris, $\mathrm{xi}+416$ pp. +46 pls. [pp. 1-64 published in 1836, pp. 65-224 in 1837, pp. 225-416 in 1838].

AUBÉ C. 1838b: Species général des hydrocanthares et gyriniens; pour faire suite au species général des coléoptères de la collection de M. le comte Dejean. Méquignon Père et Fils, Paris, xvi + 804 pp.

BALFOUR-BROWNE F. 1950: British water beetles. Volume two. Ray Society, London, 394 pp.

BALFOUR-BROWNE F. 1953: Coleoptera Hydradephaga. Handbook for the Identification of British Insects 4(3): 1-33.

BAUDI F. DI SELVE 1889: Catalogo dei coleotteri del Piemonte. Annali della Reale Accademia d'Agricoltura di Torino 32: 1-226.

BOUSQUET Y. 2016: Litteratura Coleopterologica (1758-1900): a guide to selected books related to the taxonomy of Coleoptera with publication dates and notes. ZooKeys 583: 1-776.

BRINCK P. 1955a: Gyrinidae. A monograph of the whirligig beetles of Southern Africa. South African Animal Life 1: 329-518.

BRINCK P. 1955b: A revision of the Gyrinidae (Coleoptera) of the Ethiopian region. 1. Lunds Universitets Arsskrift (Ny Följd) (Avd. 2) 51(16). Kungliga Fysiografiska Sällskapets Handlingar (Ny Följd) 66(16): 1-141.

BRINCK P. 1977: Evolution and taxonomy of Andogyrus Ochs (Coleoptera: Gyrinidae). Entomologica Scandinavica 8: 241-269.

BRODIE P. B. 1845: A history of the fossil insects in the secondary rocks of England. Accompanied by a particular account of the strata in which they occur, and of the circumstances connected with their preservation. John Van Voorst, London, xviii +130 pp. +11 pls.

BRULLÉ G. A. 1835: Histoire naturelle des insectes, comprenant leur classification, leurs moeurs, et la description des espèces. In: AUDOUIN J. V. \& BRULLÉ G. A.: Histoire naturelle des insectes traitant de leur organisation et de leurs moeurs en général, et comprenant leur classification et la description des espèces. Tome V. Coléoptères II. Pillot, Paris, 436 pp.

BRULLÉ G. A. 1837: Insectes coléoptères: tribus carabiques, hydrocanthares, palpicornes. Pp. 1-56. In: BLANCHARD E. \& BRULLÉ G. A. 1837-1842: Insectes de l'Amérique mériodionale recueillis par Alcide d'Orbigny. In: D’ORBIGNY A. D. 1835-1847: Voyage dans l'Amérique méridionale (le Brézil, la République orientale de l'Uruguay, la République Argentine, la Patagonie, la République du Chili, la République de Bolivie, la République du Perou) exécuté pendant les années 1826, 1827, 1828, 1829, 1830, 1831, 1832 et 1833 par Alcide d'Orbigny. Tome sixième. 2.e partie: Insectes. P. Bertrand \& $V^{\mathrm{e}}$ Levrault, Paris \& Strasbourg, vi +222 pp. +32 pls.

COLPANI D., BENETTI C. J. \& HAMADA N. 2014: A checklist of the Gyrinidae (Coleoptera: Adephaga) of Brazil. Zootaxa 3889: 185-213.

DEJEAN P. F. M. A. 1833: Catalogue des coléoptères de la collection de M. le comte Dejean. Livraisons $1 \& 2$. Méquignon-Marvis, Paris, $176 \mathrm{pp}$.

DEJEAN P. F. M. A. 1836-1837: Catalogue des coléoptères de la collection de M. le comte Dejean. Troisième édition, revue, corrigée et augmentée. Méquignon-Marvis Père et Fils, Paris, xiv + 503 pp. 
[Livraisons 1-4 (pp. 1-384) published in 1836; Livraison 5 (pp. i-xiv + 385-503) published in 1837].

EVENHUIS N. L. 1997: Litteratura taxonomica Dipterorum (17581930). Volume I: A-K, Volume II: L-Z. Backhuys Publishers, Leiden, $426+445 \mathrm{pp}$.

EVENHUIS N. L. 2014: Dates of the Leipzig Book Fairs (1758-1860), with notes on the book catalogs. Sherbornia 1: 1-4.

FABRICIUS J. C. 1775: Systema entomologiae, sistens Insectorum classes, ordines, genera, species adiectis synonymis, locis, descriptionibus, observationibus. Libraria Korte, Flensburgi et Lipsiae, xxxii + 832 pp.

FABRICIUS J. C. 1787: Mantissa Insectorum sistens species nuper detectas adiectis characteribus genericis, differentiis specificis, emendationibus, observationibus. Tom. 1. C. G. Proft, Hafniae, $\mathrm{xx}+348$ pp.

FABRICIUS J. C. 1792: Entomologia systematica emendata et aucta. Secundum classes, ordines, genera, species adjectis synonimis, locis, observationibus, descriptionibus. Tomus I. Pars I. C. G. Proft, Hafniae, $x x+330$ pp.

FERY H. 2020: Infrasubspecific or subspecific - a comment on Article 45.6 of the ICZN Code. Latissimus 46: 17-18.

FERY H. \& HÁJEK J. 2016: Nomenclatural notes on some Palaearctic Gyrinidae (Coleoptera). Acta Entomologica Musei Nationalis Pragae 56: 645-663.

FORSBERG C. P. 1821: De gyrinis. Nova Acta Regiae Societatis Scientiarium Upsaliensis 8: 297-313.

FRANCISCOLO M. E. 1979: Coleoptera: Haliplidae, Hygrobiidae, Gyrinidae, Dytiscidae. Fauna d'Italia, Vol. 14. Edizioni Calderini, Bologna, 804 pp.

FRIDAY L. E. 1988: A key to the adults of British water beetles. Field Studies 7: 1-151.

GERMAR E. F. 1823: Insectorum species novae aut minus cognitae, descriptionibus illustratae. Cum Tab. aen. II. J. C. Hendelii et Filii, Halae (1824), 624 pp. +2 pls.

GIEBEL C. G. 1856: Fauna der Vorwelt mit steter Berücksichtigung der lebenden Thiere. Zweiter Band: Gliederthiere. Erste Abtheilung: Insecten und Spinnen. F. A. Brockhaus, Leipzig, XVIII + 511 pp.

GÓMEZ LUTZ M. C. 2014: Estructura y dinámica de las poblaciones acuáticas de Coleoptera (Insecta) en ambientes con hidroperiodos diferentes de Corrientes, Argentina [PhD thesis]. Universidad Nacional de La Plata, La Plata, xiv + 190 pp.

GUSTAFSON G. T. \& MILLER K. B. 2013: On the family- and genusseries nomina in Gyrinidae Latreille, 1810 (Coleoptera, Adephaga) Zootaxa 3731: 77-105.

GUSTAFSON G. T. \& MILLER K. B. 2016: Revision of the southeast Asian whirligig beetle genus Porrorhynchus Laporte, 1835 (Gyrinidae: Gyrininae: Dineutini). Coleopterists Bulletin 70: 675-714.

GUSTAFSON G. T. \& MILLER K. B. 2017: Systematics and evolution of the whirligig beetle tribe Dineutini (Coleoptera: Gyrinidae: Gyrininae). Zoological Journal of the Linnean Society 20: 1-33.

GUSTAFSON G. T. \& SHORT A. E. Z. 2017: Review of the whirligig beetle genus Gyrinus of Venezuela (Coleoptera: Gyrinidae). Acta Entomologica Musei Nationalis Pragae 57: 479-520.

GYLLENHAL L. 1808: Insecta Suecica descripta. Classis I. Coleoptera sive Eleutherata. Tomus I. [Pars I.]. F. J. Leverentz, Scaris, xii + 572 pp.

HACKETHAL S. 1995: Friedrich Sellow (1789-1831). Skizzen einer unvollendeten Reise durch Südamerika. Fauna und Flora in Rheinland-Pfalz 17: 215-228.

HÁJEK J. 2012: A new substitute name for Bidessus (Bidessodes) plicatus Zimmermann, 1921 (Coleoptera: Dytiscidae: Hydroporinae: Bidessini). Zootaxa 3326: 67-68.

HÁJEK J. \& FERY H. 2017: Family Gyrinidae Latreille, 1810. Pp. 22-29. In: LÖBL I. \& LÖBL D. (eds): Catalogue of Palaearctic Coleoptera. Volume 1. Archostemata-Myxophaga-Adephaga. Revised and updated edition. Brill, Leiden, Boston, xxxiv +1443 pp.

HANDLIRSCH A. 1906-1908: Die fossilen Insekten und die Phylogenie der rezenten Formen. Ein Handbuch für Paläontologen und Zoologen. Wilhelm Engelmann, Leipzig, ix +1430 pp. +51 pls [pp. ix $+1-c a$ $672+$ pls $1-36$ in 1906 ; pp. ca. $673-$ ca. $1155+$ pls $37-51$ in 1907 ; pp. ca. 1156-1430 in 1908].

HATCH M. H. 1926: The phylogeny and phylogenetic tendencies of Gyrinidae. Papers of the Michigan Academy of Science, Arts and Letters 5 [1925]: 429-467.
HEYDEN L. von, REITTER E. \& WEISE J. 1906: Catalogus Coleopterorum Europae, Caucasi et Armeniae Rossicae. Friedländer \& Sohn etc., Berlin, Paskau, Caen, 775 pp.

HOLMEN M. 1987: The aquatic Adephaga (Coleoptera) of Fennoscandia and Denmark. I. Gyrinidae, Haliplidae, Hygrobiidae and Noteridae. Fauna Entomologica Scandinavica 20: 1-168.

HORN W., KAHLE I., FRIESE G. \& GAEDIKE R. 1990: Collectiones entomologicae, ein Kompendium über den Verbleib entomologischer Sammlungen der Welt bis 1960. Teil II: L-Z. Akademie der Landwirtschaftswissenschaften der DDR, Berlin, pp. 223-573.

ICZN 1999: International Code of Zoological Nomenclature. Fourth edition. The International Trust for Zoological Nomenclature, London, 306 pp.

KLUG J. C. F. 1829: Preis-Verzeichniss vorräthiger Insectendoubletten des Königl. Zoologischen Museums der Universität. Berlin, 18 pp.

KLUG J. C. F. 1834: Symbolae physicae, seu icones et descriptiones Insectorum, quae ex itinere per Africam borealem et Asiam occidentalem Friderici Guilelmi Hemprich et Christiani Godofredi Ehrenberg studio novae aut illustratae redierunt. - Insecta. Decas quarta. Officina Academica, Berolini, [40] pp. + pls XXXI-XL.

KLUG J. C. F. 1850: Verzeichniss verkäuflicher Doubletten der entomologischen Sammlung der Königlichen Universität zu Berlin. Akademische Buchdruckerei, Berlin, 20 pp.

LAPORTE F. L. CAUMONT DE 1834-1835: Études entomologiques. Première partie. Méquignon-Marvis Père et Fils, Paris, 159 pp. [pp. 1-94 published in 1834; pp. 95-159 in 1835].

LINGAFELTER S. W. \& NEARNS E. H. 2013: Elucidating Article 45.6 of the International Code of Zoological Nomenclature: A dichotomous key for the determination of subspecific or infrasubspecific rank. Zootaxa 3709: 597-600.

MACLEAY W. S. 1825: Annulosa Javanica, or an attempt to illustrate the natural affinities and analogies of the insects collected in Java by Thomas Horsfield, M.D. F.L. \& G.S. and deposited by him in the museum of the honourable East-India Company. Number I. Kingsbury, Parbury \& Allen, London, xii + 150 pp.

MAZZOLDI P. 1995: Gyrinidae: Catalogue of Chinese Gyrinidae (Coleoptera). Pp. 155-172. In: JÄCH M. A. \& JI L. (eds): Water Beetles of China Vol. 1. Zoologisch-Botanische Gesellschaft in Österreich and Wiener Coleopterologenverein, Wien, 410 pp.

MAZZOLDI P. 2003: Family Gyrinidae Latreille, 1810. Pp. 26-33. In: LÖBL I. \& SMETANAA. (eds): Catalogue of Palaearctic Coleoptera, Volume 1, Archostemata-Myxophaga-Adephaga. Apollo Books, Stenstrup, $819 \mathrm{pp}$.

MOTSCHULSKY V. DE 1853: Hydrocanthares de la Russie. Imprimerie de la Société de Litérature Finnoise, Helsingfors, 15 pp.

NEL A. 1989: Les Gyrinidae fossiles de France (Coleoptera). Annales de la Société Entomologique de France, Nouvelle Série 25: 321-330.

NILSSON A. N. 1998: Ádám's checklist of Hungarian Dytiscidae and the stability of nomenclature. Latissimus 10: 1-3.

NILSSON A. N. \& HÁJEK J. 2020: A world catalogue of the family Dytiscidae, or the diving beetles (Coleoptera, Adephaga). Version 1.I.2020. Distributed as a PDF file via Internet. Available from: http:// www.waterbeetles.eu (accessed December 12, 2020).

OCHS G. 1924: Über neue und interessante Gyriniden aus dem British Museum in London. Entomologische Blätter 20: 228-244.

OCHS G. 1926: Die Dineutini. 2. Tribus der Unterfam. Enhydrinae, Fam. Gyrinidae (Col.) (Fortsetzung). Entomologische Zeitschrift 40: 190-197.

OCHS G. 1927a: Ueber sibirische Gyriniden. Entomologische Zeitschrift 41: 46-49.

OCHS G. 1927b: Über die Gyriniden von Linné und Fabricius. Koleopterologische Rundschau 13: 34-42.

OCHS G. 1929: Bestimmungstabelle der Gyrinidengattung Gyretes Brullé nebst Neubeschreibungen und kritischen Bemerkungen. Koleopterologische Rundschau 15: 62-93.

OCHS G. 1935: Die brasilianische Artengruppe der Gattung Gyrinus, Untergattung Neogyrinus Hatch (Col. Gyrinidae). Revista de Entomología 5: 124-132.

OCHS G. 1949: A revision of the Gyrinoidea of Central America (Col.). Revista de Entomología 20: 253-300. 
OCHS G. 1953: Der jetzige Stand unserer Kenntnisse über die Gyriniden-Fauna von Venezuela. Acta Biológica Venezuelica 1: 181-208.

OCHS G. 1954: Die Gyriniden Perus und der übrigen südamerikanischen Kordilleren. Beiträge zur Fauna Perus 4: 116-155.

OLIVIER G. A. 1791-1792: Encyclopédie méthodique. Histoire naturelle. Insectes. Tome sixième. Panckoucke, Paris, 704 pp. [pp. 1-368 (livraison 47) published on 21 November 1791; pp. 369-704 (livraison 51) published on 1 October 1792].

OLIVIER G. A. 1795: No. 41. Gyrin, Gyrinus. Pp. 1-14. In: Entomologie, ou histoire naturelle des insectes, Avec leurs caractères génériques et spécifiques, leur description, leur synonymie, et leur figure enluminée. Coléoptères. Tome troisième. Lanneau, Paris, 557 pp. +65 pls [each genus separately paginated].

PAYKULL G. von 1798: Fauna Suecica. Insecta. Tomus 1. Joh. F. Edman, Uppsaliae, $\mathrm{x}+358 \mathrm{pp}$.

PREUDHOMME DE BORRE C. F. P. A. 1886: Liste des lamellicornes laparostictiques recueillis par feu Camille van Volxem pendant son voyage au Brésil et a La Plata en 1872 suivie de la description de dix huit espèces nouvelles et un genre nouveau. Annales de la Société Entomologique de Belgique 30: 103-120.

RÉGIMBART M. 1882-1883a: Essai monographique de la famille des Gyrinidae. $1^{\text {re }}$ partie. Annales de la Société Entomologique de France $\sigma^{e}$ Série 2: 379-458 + pls 10-12 [pp. 379-400 published in 1882, pp. $401-458$ in 1883].

RÉGIMBART M. 1883b: Essai monographique de la famille des Gyrinidae. $2^{\mathrm{e}}$ partie. Annales de la Société Entomologique de France, 6 Série 3: 121-190.

RÉGIMBART M. 1884: Essai monographique de la famille des Gyrinidae. $3^{\mathrm{e}}$ Partie. Annales de la Société Entomologique de France, $6^{e}$ Série 3 [1883]: 381-482 + pls 11-14 [= V-VIII].

RÉGIMBART M. 1892: Essai monographique de la famille des Gyrinidae. $2^{\mathrm{e}}$ supplément. Annales de la Société Entomologique de France $\mathbf{6 0}$ [1891]: 663-752 + pls 18-19.

RÉGIMBART M. 1903: Liste des Dytiscidae \& Gyrinidae recueillis par le Dr Philippe Silvestri dans l'Amerique méridionale de 1898 à 1900. Bullettino della Società Entomologica Italiana 35: 46-74.

SCHMIDT O. C. F. G. 1844: Catalogus Coleopterorum Europae (2. ed.). Entomologischer Verein, Stettin, 76 pp. +6 pp. [unpag.].

SHARP D. 1878: Aquatic Coleoptera collected by M. Camille van Volxem in Brazil. Annales de la Société Entomologique de Belgique 20 [1877]: 116-119.
SHERBORN C. D. 1926: Index animalium sive index nominum quae ab a.d. MDCCLVIII generibus et speciebus animalium imposita sunt. Part XI. Index: funereus-gyzehensis. 1801-1850. British Museum, London, pp. 2569-2880.

SHERBORN C. D. 1929: Index animalium sive index nominum quae ab a.d. MDCCLVIII generibus et speciebus animalium imposita sunt. Part XVIII. Index: o-nigrum-pallens. 1801-1850. British Museum, London, pp. 4451-4690.

STEPHENS J. F. 1829: A systematic catalogue of British insects. Part 1. Baldwin \& Cradock, London, xxxiv $+416 \mathrm{pp}$.

STURM J. 1843: Catalog der Käfer-Sammlung von Jacob Sturm. Privately printed, Nürnberg, xii +386 pp. +6 pls.

THUNBERG C. P. 1781: Dissertatio entomologica novas Insectorum species, sistens, cujus partem primam. Edman, Upsaliae, 28 pp. +1 pl.

VIDAL SARMIENTO J. A. 1959: Estudios de los genitales machos en coleópteros adéfagos. Notas del Museo de La Plata (Zoología) 19: $223-242$.

WALLENGREN H. D. J. 1881: Coleoptera Transvaaliensia. Bidrag till kännedom om Transvaal-landets i S. Afrika coleopter-fauna. Entomologisk Tidskrift 2: 9-22.

WALLIS J. B. 1926: Some new Coleoptera. Canadian Entomologist 58: 89-95.

WHITE A. 1847: Nomenclature of coleopterous insects in the collection of the British Museum. Part II. Hydrocanthari. Edward Newman, London, $59 \mathrm{pp}$.

WIEDEMANN C. R. W. \& GERMAR E. F. 1821: Neue exotische Käfer. Magazin der Entomologie 4: 107-183.

ZAITZEV F. A. 1908: Berichtigungen und Zusätze zu den Haliplidae, Dytiscidae und Gyrinidae in den neuesten Katalogen der Coleopteren. Revue Russe d'Entomologie 7 [1907]: 114-124.

ZIMMERMANN A. 1921: Beiträge zur Kenntnis der südamerikanischen Schwimmkäferfauna nebst 41 Neubeschreibungen. Archiv für $\mathrm{Na}$ turgeschichte, Abteilung A 87: 181-206.

ZIMSEN E. 1964: The type material of I.C. Fabricius. Munksgaard, Copenhagen, $656 \mathrm{pp}$.

ZISCHLER H., HACKETHAL S. \& ECKERT C. (eds) 2013: Die Erkundung Brasiliens. Friedrich Sellows unvollendete Reise. Galiani, Berlin, 253 pp. 
